\title{
SETTLEMENT OF INTERNATIONAL DISPUTES BY AND BETWEEN THE ENGLISH SPEAKING PEOPLES*
}

\author{
(Second Article.) \\ By the Honorable William Renwick Riddell, L.H.D., LL.D., \\ Justice, Supreme Court of Ontario (A'ppellate Division). \\ Thus far particular treaties and conventions have been spoken \\ of; it remains to consider the general agreements. \\ *"In I908, April 4, a general Treaty of Arbitration between the \\ United States and Great Britain was signed at Washington. This \\ provided (Article I) that differences which might arise of a legal \\ nature or relating to the interpretation of treaties existing be- \\ tween the two contracting parties, and which could not be settled \\ by diplomacy, should be referred to the permanent Court of Arbi- \\ tration established at The Hague by the convention of July 29, \\ r899, provided they did not affect the vital interests, the inde- \\ pendence or the honor of the two contracting States and did not \\ concern the interests of third parties.
}

"Article II provides that in each individual case the parties were to conclude a special agreement defining the matter in dispute, the scope of the powers of the arbitrators and the times to. be set for the several stages of the procedure.

"A provision of very great significance to a Canadian appears in the Treaty. The British Government reserved the right before concluding a special agreement in any matter affecting the interests of a self-governing Dominion of the British Empire to obtain the concurrence therein of the Government of that Dominion.

"This was not indeed the first time the concurrence of the colony had been provided for; in the Treaty of Washington (I87I) it was provided that certain parts of the Treaty were not. to come into force until legislation had been passed by the colonies. concerned."

* The quotations are from an address before the American Society for the Judicial Settlement of International Disputes, delivered December 15, 1910, published (in part) by the Maryland Peace Society, February, 1911, as No. 5 of their Series of Publications.

NoTE.-There is no pretence to originality in this paper; and all persons are invited to make such use of it as they see fit.-W. R. R. 
It was under this General Treaty that The Hague arbitration $\left(21^{\circ}\right.$ above) was held.

This Treaty, it will be seen, applies to the whole British Empire: but there is another international arrangement which (as I said in an address at Washington some years ago) "may be called a miniature Hague tribunal of our own just for us Englishspeaking nations of the Continent. of North America."

This "Treaty of Igog was preceded by the constitution of a board of commissioners. This board was formed at the request of the President, acting under the authority of the River and Harbor Act approved June 13, I902. The functions of the proposed board were defined in the Act and were substantially a full investigation of the question of the boundary waters; and the board was to consist of six members, three appointed by the United States and three by Canada. The President, July I5, I902; communicated through the American Ambassador at London-with the British Government, that government transmitted the invitation to the government at Ottawa, the Canadian Government accepted the invitation, and this acceptance was communicated to the American Government. The American part of the board was appointed in 1903 and the Canadian in 1903 and I905; and work was begun with all convenient speed on the Sault Ste Marie 'Channel, the Chicago Canal, the Minnesota Canal, etc. This board has done an immense amount of very valuable work already.

"The Treaty of 1909 was really at the instance of that board." Signed January II, I909, this "Waterways Treaty" provides "for the establishment and" maintenance of an International Joint Commission of the United States and Canada-three appointed by each government- which commission should (Article VIII) have jurisdiction over and pass upon all cases involving the use, obstruction or diversion of the waters between the United States and Canada. But Airticle IX contains an agreement that all matters of difference between the countries involving the rights, obligations or interests of either in relation to the other -or to the inhabitants of the other along the frontier shall be referred to this commission for inquiry and report. Article $\mathrm{X}$ provides that any questions or matters of difference involving the rights, obligations or interests of the United States or of Canada, either in relation to each other or to their respective inhabitants may be referred for decision to this International Joint Commission. If the commission be equally divided, an umpire is to be chosen in the manner provided by Act 45 of The Hague convention of October I8, I907."

It will be seen that "every dispute involving the rights, obligations or interests of the United States or of the Dominion of 
Canada either in relation to each other or to their respective inhabitants may be referred to the commission by the consent of the two countries.

"It is hard to see how a more comprehensive clause could be framed; and if the Treaty had provided that such dispute "shall" be referred, the work would be perfect. As it is, the Dominion must give consent through the Dominion Cabinet. That is an easy task. We have a government which is united-it must be united or it could not stand-and which in this instance does not need to go to Parliament for authority."

It is not always the case that a Canadian Parliament will consent to an international agreement made by the Government; then the Government must take the opinion of the electorate (a recent example will occur to everybody) - but in this instance, the Government may act without the consent of Parliament.

"But in the United States the action must be by and with the advice and consent of the Senate; and sometimes, as is well known, trouble arises in the Senate about confirming treaties.

"Each reference to the Commission will or may be but equivalent to making a new treaty. Had the provision been that the consent might be given by the President of the United States, the position of the parties on the two sides would have been much alike.

"Better even than this would be a provision making the arbitration of the commission apply automatically. If such a provision proved unsatisfactory, the treaty could be denounced and a new treaty negotiated. But I suppose there may be some jealousy on the part of the Senate, or perhaps the Constitution prevents. And we Canadians notice that the Constitution of the United States prevents a great many things being done over which we should have no trouble at all."

The Rush-Bagot Convention of I8I7 cannot fairly be called an agreement of the kind we have been considering-it was designed to prevent troubles arising, not to settle them after they had arisen. It may be well, however, to say a word about it here.

"During the War of I8I2 much damage had been done by armed vessels upon the Great Lakes. The Treaty of Ghent did not provide that such armed forces should not be kept up; but it became apparent to both sides that it would be well strictly to limit the number and quality of armed vessels upon the fresh waters between the two countries. After some negotiation notes were interchanged April 28 and 29, I8I\%, containing the "RushBagot convention," which notes contained an agreement by one 
and the other party limiting the naval force to be kept on the lakes to a very few: on Lake Ontario one vessel, on the Upper Lakes two vessels, on Lake Champlain one vessel, none of the vessels to exceed one hundred tons burden, and each to have but one cannon of 18 pounds. It was agreed to dismantle forthwith all other armed vessels on the Lakes, and that no other vessels of war should be there built or armed; six months' notice to be given: by either party of desire of annulling the stipulation.

"The arrangement was after some delay submitted by the President to the Senate, and that body in I8I8 approved of and consented to it."

This understanding has continued up to the present time-perhaps not always so strictly observed as might be desired.

"The understanding was, however, in great danger in 1864 . The Minister of the United States in London was instructed in October of that year to give the six months' notice required to. terminate the agreement; and $\mathrm{Mr}$. Adams did so, with the subsequent approval of Congress. Before the lapse of the time specified, however, matters on the lakes had taken a different turn, and the United States expressed a desire that the arrangement should continue and be observed by both parties. This was acceded to. and all parties thereafter considered the convention to be in full force."

I say nothing of Treaties which have been negotiated and havefailed of ratification, or of negotiations which proved fruitless. even diplomatically.

It is by no means without interest to note the various methods. of selecting the trial tribunal.

(a) The first scheme was for each party to appoint one representative, and before entering upon the enquiry, these two to. select a third Commissioner; in case of their inability to agree, this third to be selected by lot from two named, one by each Commissioner. This made a board of three commissioners through-. out. Nos. $I^{\circ}, I I^{\circ}, I 2^{\circ}$.

(b) In the same Treaty another clause provided for five Commissioners, two appointed by each party and the fifth chosen as. in the scheme $(a)$. This arbitration was about money, which has always been a most important matter in the "Anglo-Saxon" world. Three Commissioners were enough to determine a merematter of territory, but when it came to be a question of determining the amount of money to be paid, five were needed. (Even at the present day a rough can kick his wife's ribs in with a pen- 
alty of 30 days in the workhouse or common gaol, but let him steal a two-dollar bill and it is five years in the penitentiary.) This scheme is, however, practically the same as the former. Nos. $2^{\circ}, 3^{\circ}$.

(c) Not very different was the appointment of one representative by each Government, and the third by the Governments jointly, if they could not agree the third to be appointed by a foreign potentate or his representative. Nos. $15^{\circ}$ (the Spanish Minister at Washington), $16^{\circ}$ (the Austrian Ambassador at London).

(d) Or instead of forming a board thus, the Commissioners appointed by the parties were directed to enter upon the enquiry, and in particular cases where they were unable to agree, they were to call in an umpire. This umpire might be selected by lot from persons named by the two Governments (No. $9^{\circ}$ ) or by the Commissioners, with a provision as in (e) (No. $\left.13^{\circ}, 19^{\circ}\right)$.

(e) The Commissioners may not be allowed to appoint an umpire: but must, if possible, dispose of the difficulties themselvesin case of failure, reporting to their respective Governments (Nos. $4^{\circ}, 5^{\circ}, 6^{\circ}$ ), or having recourse to an agent of a foreign power $\left(\right.$ No. $\left.8^{\circ}\right)$.

( $f$ ) A board may be formed of an equal number of representatives appointed by each party. No. $20^{\circ}$.

(g) Or an equal number appointed by each party and three others by foreign powers. Nos. $14^{\circ}, 18^{\circ}$.

(h) A friendly sovereign may be asked to determine the matter in dispute. (Nos. $7^{\circ}$ (the Emperor of Russia), 10 (the King of the Netherlands), $I 7^{\circ}$ (the Emperor of Germany).

(i) Finally the Tribunal of Arbitration provided by The Hague may be appealed to. No. $2 \mathrm{I}^{\circ}$.

Success in determining the questions submitted has generally been achieved. Nos. $2^{\circ}, 5^{\circ}, 9^{\circ}, 10^{\circ}$, were exceptions-No. $5^{\circ}$, from the difficulties inherent in the subject matter: the same remark applies partially to $\mathrm{No} .10^{\circ}$, but in this case there was a neglect to decide judicially. No. $2^{\circ}$ seems to have been hampered by faults of temper biut there does not seem to have been any good reason why the difficulties in both this case and in No. $5^{\circ}$ should not have been overcome. The two Governments, however, took the short cut and determined the matters themselves.

In the cases in which an award was made there does not seem to have been any feeling of injustice, or at least any considerable public expression of such feeling in Nos. $1^{\circ}, 3^{\circ}, 4^{\circ}, 5^{\circ}, 6^{\circ}, 7^{\circ}, 8^{\circ}$, 
$\mathrm{Ir} \mathrm{I}^{\circ}, \mathrm{I} 2^{\circ}, 13^{\circ}, \mathrm{I} 5^{\circ}, 17^{\circ}, 18^{\circ}, 19^{\circ}, 21^{\circ}$, 一the award in No. $10^{\circ}$ was repudiated by the United States with the consent of Great Britain. The Alabama award, No. $14^{\circ}$, was received with considerable indignation in Britain, where Sir Alexander Cockburn's conduct was very generally approved.

No. $16^{\circ}$, the Halifax Award, was equally objectionable to many in the United States, and No. $20^{\circ}$, the Alaska Award, created much anger amongst the Canadian people, a large proportion of whom thought they had been tricked in the constitution of the Board and that the decision given was not a judicial decision, but acquiesced in for diplomatic reasons.

In none of these cases, however, notwithstanding the fact that the representatives of the losing party refused to concur in the award, was there a repudiation. The anger was short-lived and little if any evil after effect remains. The right which every unsuccessful litigant has of damning the judge was. freely exercised; that acted to a certain extent as a safety valve, and the indignation has blown off. Perhaps the most marked success has been achieved in the last award. Made as it was by judges and jurists of repute, the Court determined everything (except one minor point) by a unanimous judgment: and even in the point upon which there was a dissent, those directly representing the two contending nations agreed in their opinion. Both parties, too, were perfectly satisfied with the result, and no word of complaint was heard against the Court or any member of it, or against the award or any part of it. $O$ si sic omnia. After all the experiments, the true way seems to have been found.

There is another consideration which may be mentioned. The savage has probably as much law as the most civilized-the main difference is that with the former each case is decided without regard to any other, past or future, or to any general rule. As men become more civilized, they look before and after, law becomes systematized, the king or judge (the terms are not seldom synonymous) no longer gives a sentence the result of direct inspiration in the particular case, but rather one in accordance with a general rule believed to be on the whole advantageous to the community.

An arbitration bears the same relation to a Court as the separate isolated judgment in a separate isolated case bears to a judgment based upon a general rule. No one can draw any principle of international law or any rule for national conduct from the 
decision of a board of arbitrators-they decide simply what seems advisable in the particular case.

But once establish a Court with anything like a permanent Constitution and the case is different-principle must take the place of mere expediency. The decisions of a permanent Court are, as a matter of course, reported, and in any case are a guide for the Court in all future references.

And what is, perhaps, still more important, a Bar will form whose business it is to study decisions of this Court, to deduce principles therefrom and assist the Court in arriving at a decision in accordance with the true principles. No one who knows how the Bar in English-speaking countries has strengthened the Courts and aided them in maintaining the confidence of the people needs to be told of the advantages of a strong Bar. Nothing better has yet been devised to do justice and give every man his due than an impartial Court aided by a learned Bar. The Hague offers the first and the second would soon grow up around the Court.

It is not too much to hope that arbitration will disappear and judicial decision be the rule, at least between these kindred nations.

In any case, the worst result by such peaceful means, even by arbitration, is better than the best by war.

Toronto, April I2th, I9I3. 